\title{
Molecular mechanism of peritoneal dissemination in gastric cancer
}

\author{
Qing-Jiang Hu',2, Shuhei Ito', Kazuyoshi Yanagihara ${ }^{3}$, Koshi Mimori' \\ 'Department of Surgery, Kyushu University Beppu Hospital, Beppu 874-0838, Japan. \\ ${ }^{2}$ Department of Surgery and Science, Kyushu University Hospital, Fukuoka 812-8582, Japan. \\ ${ }^{3}$ Division of Biomarker Discovery, Exploratory Oncology Research \& Clinical Trial Center, National Cancer Center, Kashiwa 277- \\ 8577, Japan.
}

\begin{abstract}
Correspondence to: Dr. Koshi Mimori, Department of Surgery, Kyushu University Beppu Hospital, 4546 Tsurumihara, Beppu 874-0838, Japan. E-mail: kmimori@beppu.kyushu-u.ac.jp
\end{abstract}

How to cite this article: Hu QJ, Ito S, Yanagihara K, Mimori K. Molecular mechanism of peritoneal dissemination in gastric cancer. J Cancer Metastasis Treat2018;4:39. http://dx.doi.org/10.20517/2394-4722.2018.08

Received: 3 Feb 2018 First Decision: 8 Feb 2018 Revised: 13 Jun 2018 Accepted: 25 Jun 2018 Published: 26 Jul 2018

Science Editor: Masayuki Watanabe Copy Editor: Jun-Yao Li Production Editor: Cai-Hong Wang

\begin{abstract}
Peritoneal dissemination (PD) is the most common cause of metastasis in gastric cancer (GC). Because there are no standard treatments for $\mathrm{PD}$, it is associated with a poor prognosis. Although clinicians have performed intraperitoneal chemotherapy for GC with PD, the outcome remains unsatisfactory. Therefore, the development of novel treatments and diagnostic tools for PD is expected to improve the prognosis of GC patients with PD. Notably, it is essential to elucidate the molecular mechanisms involved in the development of PD in GC. In this review, the molecular mechanisms of PD (three steps: detachment from the primary tumor, adaptation to the microenvironment of the peritoneal cavity, and attachment to peritoneal mesothelial cells) and new topics in GC are highlighted.
\end{abstract}

Keywords: Gastric cancer, peritoneal dissemination, molecular mechanism

\section{INTRODUCTION}

Gastric cancer (GC) is one of the most prevalent cancers worldwide and is associated with a high mortality rate $^{[1]}$. The malignant potential of GC is characterized biologically by the dissemination of cancer cells from the primary site throughout the peritoneal cavity. Almost 50\% of recurrence was peritoneal dissemination in GC, and GC patients with peritoneal dissemination (PD) had a poor prognosis ${ }^{[2]}$. Although molecularly-targeted therapy has improved the prognosis of advanced and recurrent GC, the outcome remains unsatisfactory particularly in GC patients with $\mathrm{PD}^{[3,4]}$. Therefore, clarification of the

\footnotetext{
(a) (1)

(C) The Author(s) 2018. Open Access This article is licensed under a Creative Commons Attribution 4.0 International License (https://creativecommons.org/licenses/by/4.0/), which permits unrestricted use, sharing, adaptation, distribution and reproduction in any medium or format, for any purpose, even commercially, as long as you give appropriate credit to the original author(s) and the source, provide a link to the Creative Commons license, and indicate if changes were made.
}

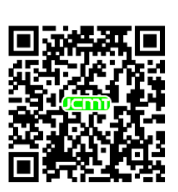



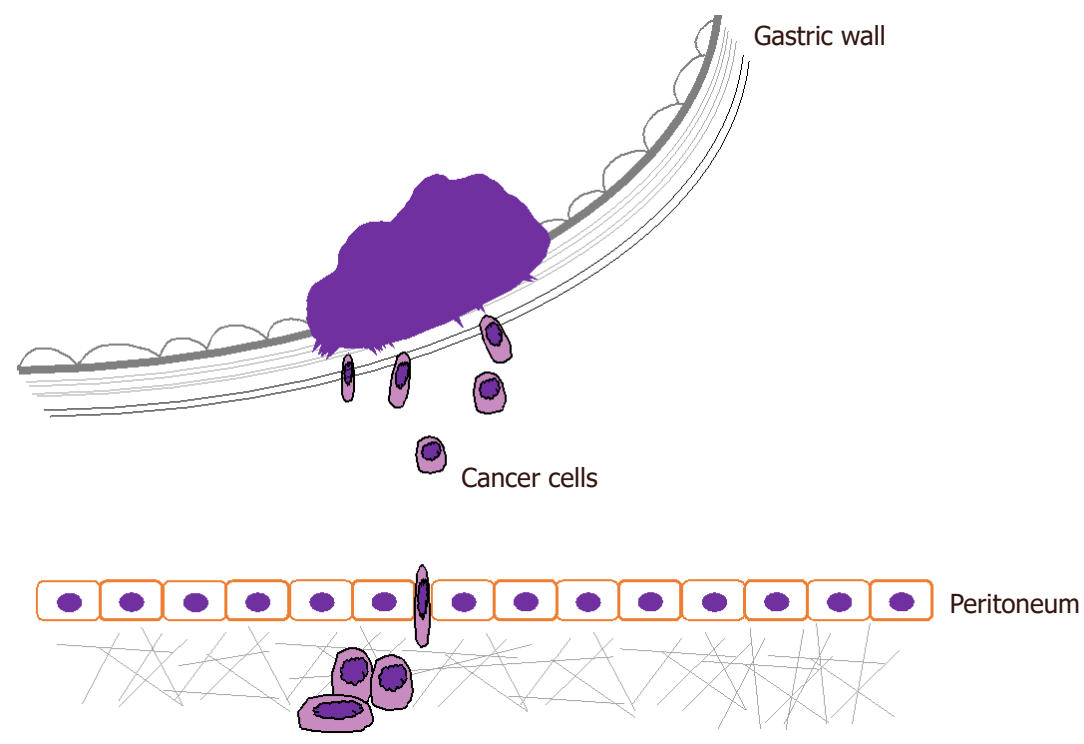

Figure 1. The metastatic cascade of peritoneal dissemination in gastric cancer

Table 1. The major molecules involved in development of peritoneal dissemination in gastric cancer

\begin{tabular}{|c|c|c|c|c|}
\hline & Molecule & Biological function & $\begin{array}{c}\text { Associated molecules/ } \\
\text { pathways }\end{array}$ & References \\
\hline \multirow[t]{2}{*}{$\begin{array}{l}\text { Detachment from the } \\
\text { primary tumor }\end{array}$} & E-cadherin & Cell-cell adhesion & $\begin{array}{l}\text { Wnt, Rho GTPase, NF-кB } \\
\text { pathway, EMT }\end{array}$ & [14-19] \\
\hline & ARL4C & GTP-binding protein & Rho GTPase, EGF, Wnt & {$[23,24]$} \\
\hline \multirow[t]{6}{*}{$\begin{array}{l}\text { Adaptation to the peritoneal } \\
\text { cavity microenvironment }\end{array}$} & HIF1 $\alpha$ & $\begin{array}{l}\text { Regulation of cellular and } \\
\text { systemic homeostatic } \\
\text { responses to hypoxia }\end{array}$ & $\begin{array}{l}\text { EMT, NF-кB pathway, } \\
\text { Glucose metabolism }\end{array}$ & [39-42] \\
\hline & LOX & Lysyl oxidase & EMT & [43] \\
\hline & ANGPTL4 & Resistance to anoikis & FAK/Src/PI3K/Akt/ERK & {$[46]$} \\
\hline & CXCL12 & Chemokine ligand & EMT, CXCL12/CXCR4 & {$[55,56]$} \\
\hline & Akt & Serine-threonine kinase & $\begin{array}{l}\text { PI3K/Akt, PTEN/PI3K/ } \\
\text { NF-KB/FAK }\end{array}$ & {$[50-54]$} \\
\hline & FAK & Tyrosine kinase & $\mathrm{Fak} / \mathrm{Src}$ & {$[53,54]$} \\
\hline \multirow{2}{*}{$\begin{array}{l}\text { Attachment toperitoneal } \\
\text { mesothelial cells and tumor } \\
\text { growth }\end{array}$} & Integrin a3b1 & Cell adhesion & Lamine-5 & {$[63]$} \\
\hline & VEGF & $\begin{array}{l}\text { Vascular endothelial } \\
\text { growth factor }\end{array}$ & Angiogenesis & {$[61,65-67]$} \\
\hline
\end{tabular}

molecular mechanisms of PD is important for developing novel therapies and improving the clinical outcomes of GC patients.

The metastatic cascade of GC consists of lymphatic metastasis, hematogenous metastasis, and PD. Although the lymphatic metastasis and hematogenous metastasis are the major dissemination processes in solid cancers, PD is the most frequent metastatic type in GC patients, according to the annual report 2009 from Japanese Gastric Cancer Association. Unlike the lymphatic metastasis and the hematogenous metastasis, the peritoneal dissemination is initially driven by direct invasion from gastric wall to the peritoneal cavity.

Many metastasis-related factors, such as adhesion molecules, matrix proteases, and motility factors, are involved in the development of $\mathrm{PD}$, which is a multistep process ${ }^{[5-9]}$. The first step involves detachment of cancer cells from the primary tumor, followed by survival of the cells in the microenvironment of the peritoneal cavity. The last step is attachment of circulating tumor cells to peritoneal mesothelial cells and tumor growth. In this review, we highlight the major molecular mechanisms of PD [Table 1 and Figure 1] and new topics in GC. 


\section{THE DETACHMENT OF CANCER CELLS FROM THE PRIMARY TUMOR}

The development of PD is initiated by penetration of cancer cells through the gastric wall. In this step, cancer cells must have the ability to migrate and invade for successful detachment from the primary tumor and for gaining access to the peritoneal cavity. E-cadherin is a calcium-dependent cell - cell adhesion molecule that plays a crucial role in establishing the epithelial architecture and maintaining cell polarity. Dysregulation of E-cadherin contributes to tumor invasion by promoting cell motility ${ }^{[10,11]}$, resulting in PD. Moreover, E-cadherin and the cadherin - catenin complex may promote invasion and migration by modulating various signaling pathways in epithelial cells, including Wnt signaling ${ }^{[12]}$, Rho GTPase ${ }^{[13,14]}$, and NF- $\kappa B$ pathways ${ }^{[15,16]}$, as well as epithelial-mesenchymal transition (EMT) $)^{[13,17]}$.

The activation of Rho GTPases (RhoA, cdc42, Rac) also drives cancer cell motility and invasion by promoting actin cytoskeleton reorganization ${ }^{[18-20]}$. The formation of lamellipodia and filopodia (resulting in actin cytoskeleton reorganization), which are regulated by Rac and cdc42, respectively, contributes to cancer cell motility ${ }^{[18]}$. In a previous study, ADP-ribosylation factor-like $4 \mathrm{C}(A R L 4 C)$, a downstream factor of EGF signaling and Wnt signaling, was reported to promote cell motility by activating Rho GTPases ${ }^{[21]}$. We recently found that $A R L 4 C$ is associated with PD in GC, possibly by promoting the invasive capacity of cancer cells via activation of both EMT and actin cytoskeleton reorganization ${ }^{[22]}$. ARL 4 C is proposed to be a novel biomarker and potential therapeutic target for GC patients with PD.

In the process of cancer cell invasion, overexpression of matrix metalloproteinases (MMPs) is required for degradation of the extracellular matrix $(\mathrm{ECM})^{[23,24]}$. High expression of MMP-7 is a reported risk factor for PD in GC ${ }^{[25]}$, and MMP-2 and MMP-9 are also associated with the invasive capacity of gastrointestinal cancer cells ${ }^{[24,26,27]}$. Furthermore, MMP-14 can activate MMP-2 in addition to degradation of $\mathrm{ECM}^{[28]}$.

EMT is an essential phenotypic conversion mechanism that has been implicated in the initiation of metastasis and tumor progression in many types of cancers ${ }^{[29]}$. During EMT, epithelial cells exhibit enhanced motility and invasiveness ${ }^{[30]}$, low expression of E-cadherin, high expression of vimentin, a spindle shape, and reduced adhesion. The major ligands involved in EMT are EGF, TGF $\beta$, Wnt, Notch, and integrin. The major transcription factors that induce EMT via downregulation of E-cadherin expression ${ }^{[13]}$ are Twist, Snail, Slug, Zeb1, and Zeb2 ${ }^{[31-33]}$. We focused on the influence of EMT on PD and found that discoidin domaincontaining receptor 2 promoted PD in GC via induction of $\mathrm{EMT}^{[34]}$.

\section{CELL SURVIVAL IN THE MICROENVIRONMENT OF THE PERITONEAL CAVITY}

The microenvironment of the free abdominal space is hypoxic and deficient in glucose ${ }^{[35]}$. The cancer cells, which are seeded in the peritoneal cavity, must survive, proliferate, and migrate in this environment. Cell adhesion to appropriate ECM components with integrin and cadherin is essential for cell survival, and loss of this adhesion induces cell death, which has been termed "anoikis". Therefore, anoikis resistance is required for cells surviving in the peritoneal cavity and anchorage-independent growth ${ }^{[36]}$.

HIF1 $\alpha$ is reportedly involved in PD in GC, colorectal cancer, and pancreatic cancer ${ }^{[35,37]}$. HIF1 $\alpha$ is induced by hypoxia and functions as a master regulator of cellular and systemic homeostatic responses to hypoxia by activating the transcription of many genes, including those involved in glucose metabolism and other adaptations to hypoxia ${ }^{[38-40]}$. Interestingly, HIF1 $\alpha$ induces EMT by activating the transcription of genes in the LOX family ${ }^{[4]}$. EMT contributes to not only migration and invasion but also anoikis resistance in cancer cells $^{[42,43]}$. HIF1 $\alpha$ also induces angiopoietin-like-4 (ANGPTL4), a secreted protein essential for tumor growth and resistance to anoikis in GC cells ${ }^{[44]}$.

Cancer cells develop anoikis resistance via several mechanisms, including changes in integrin repertoire expression, induction of EMT, oncogene activation, and adaption of their metabolism ${ }^{[45-47]}$. In gastrointestinal 
cancers, the PI3K/Akt ${ }^{[48-50]}$ and PTEN/PI3K/NF-אB/FAK pathways ${ }^{[51,52]}$ are involved in the formation of PD and anoikis resistance. FAK is a key integrin signaling molecule involved in cell survival pathways ${ }^{[51,52]}$. Moreover, the CXCL12/CXCR4 pathway can induce $\mathrm{EMT}^{[53,54]}$ and is associated with PD and anoikis resistance ${ }^{[55,56]}$ in multiple human cancers.

\section{THE ATTACHMENT OF FREE TUMOR CELLS TO PERITONEAL MESOTHELIAL CELLS AND TUMOR GROWTH}

Cancer cells seeded in the peritoneal cavity attach directly to the peritoneal surface. However, the mesothelium, a membrane composed of simple squamous epithelium that forms the lining of peritoneum, prevents the cancer cells from penetrating into the submesothelial space. The connective tissue under the mesothelium contributes to the formation of a microenvironment (niche) for seeding cancer nodules in the process of $\mathrm{PD}^{[6,57,58]}$. The production of MMPs and integrin is important for the penetration into the submesothelial space ${ }^{[59]}$. Notably, MMP-7 functions as a key factor in the degradation of ECM, promoting the penetration of cancer cells into the submesothelial space and the formation of PD. Integrins, transmembrane receptors that facilitate cell-ECM adhesion, were found to be overexpressed in GC cell lines with high PD potential ${ }^{[60]}$. Takatsuki et al.$^{[1]]}$ reported that inhibition of integrin a3b1 reduced the number of disseminated nodules in GC cells. Laminin-5, a ligand with a high affinity for integrin a3b1, is a major ECM glycoprotein. Inhibition of laminin-5 reduced the adhesion of free cells to parietal peritoneum, suggesting that integrin a3b1 plays a key role in cell penetration into the submesothelial space ${ }^{[6]}$. Recently, it was reported that mesothelial cells create a novel tissue niche that facilitates GC invasion, resulting in $\mathrm{PD}^{[62]}$.

Cancer cells that have attached to connective tissue underlying the mesothelium induce angiogenesis for tumor growth through high expression of vascular endothelial growth factor (VEGF) ${ }^{[59]}$. VEGF is a wellknown signaling protein that stimulates formation of blood vessels. Previous studies suggest that VEGF is associated with PD in $\mathrm{GC}^{[63-65]}$. VEGF receptor antisense therapy inhibited angiogenesis and PD in GC ${ }^{[65]}$. Targeting VEGF is considered an attractive strategy to inhibit PD in GC.

\section{NEW TOPICS IN GC}

Immune checkpoint inhibitors enhance antitumor T-cell activity through inhibition of immune checkpoints such as the programmed death-1 (PD-1) receptor. Recent trials showed that anti-PD-1 receptor antibodies (pembrolizumab evaluated inKEYNOTE-012 and nivolumab in ONO-4538-12) exert antitumor activity in patients with advanced GC or gastro-esophageal junction cancer ${ }^{[6,67]}$. In a subgroup analysis of theONO-4538-12 trial, there are no interactions between PD and nivolumab treatment, indicating that nivolumab is effective for treatment of GC patients with or without PD. Immune checkpoint inhibitors are expected to improve the outcome of GC patients with PD.

With the accumulation of genomic/epigenomic data, many public data and online analysis tools are now available. The Cancer Genome Atlas (TCGA) is a large cancer genome project that has accumulated RNA sequencing, exome sequencing, SNP array, DNA methylation, reverse-phase protein lysate microarray, and clinical data across multiple cancers, and these data sets can be downloaded easily. Recently, TCGA reported a molecular classification that divides GC into four subtypes [Epstein-Barr virus (EBV)-positive, microsatellite instability (MSI), genomically stable (GS), chromosomal instability (CIN)] based on integrated genomic/epigenomic data (copy number analysis, whole exome sequencing, DNA methylation arrays, RNA sequencing, microRNA arrays, protein arrays) ${ }^{[68]}$. This classification provides a consistent and unified framework for further clinical and preclinical translational research. Elucidation of the molecular characterization of PD in GC is still needed but is expected to promote the development of novel treatments for GC patients with PD. 
Recently, the perinuclear compartment (PNC), a complex nuclear structure associated with metastatic behaviors of cancer cells has drawn much attention ${ }^{[69,70]}$. Metarrestin, a PNC inhibitor, inhibits invasion in vitro, suppresses distant metastatic development in three mouse models of human cancer ${ }^{[7]}$. The invasion is required for the formation of $\mathrm{PD}$, suggesting that metarrestin could also disturb the metastatic cascade of PD. Metarrestin will be submitted to the Food and Drug Administration for approval as an investigational drug in the near future.

\section{CONCLUSION}

The formation of PD is a multistep process, in which cancer cells must detach from the primary tumor, adapt to the microenvironment of the peritoneal cavity, and develop disseminated nodules. GC is characterized by genome instability and intratumoral heterogeneity, which contribute to the development of cancer by enabling adaptation to any change in environment. The same genomic/epigenomic alterations across all clones maybe an attractive therapeutic target for GC patients with PD. Further elucidation of the molecular mechanism underlying PD is essential for developing novel treatments and improving the outcome of GC patients with PD.

\section{DECLARATIONS}

\section{Acknowledgments}

The authors would like to thank Dr. Yuta Kouyama for English proofreading in this manuscript.

\section{Authors' contributions}

Designed the study, and wrote the initial draft of the manuscript: Hu QJ

Modified the draft of the manuscript: Ito $S$

Collected and interpreted the data, and critically reviewed the manuscript: Yanagihara K, Mimori K Approved the final version of the manuscript: All authors

\section{Availability of data and materials}

Not applicable.

\section{Financial support and sponsorship}

None.

\section{Conflicts of interest}

All authors declared that there are no conflicts of interest.

\section{Ethical approval and consent to participate}

Not applicable.

\section{Consent for publication}

Not applicable.

\section{Copyright}

(c) The Author(s) 2018.

\section{REFERENCES}

1. Torre LA, Bray F, Siegel RL, Ferlay J, Lortet-Tieulent J, Jemal A. Global cancer statistics, 2012. CA Cancer J Clin 2015;65:87-108.

2. Thomassen I, van Gestel YR, van Ramshorst B, Luyer MD, Bosscha K, Nienhuijs SW, Lemmens VE, de Hingh IH. Peritoneal carcinomatosis of gastric origin: a population-based study on incidence, survival and risk factors. Int J Cancer 2014;134:622-8. 
3. Wilke H, Muro K, Van Cutsem E, Oh SC, Bodoky G, Shimada Y, Hironaka S, Sugimoto N, Lipatov O, Kim TY, Cunningham D, Rougier P, Komatsu Y, Ajani J, Emig M, Carlesi R, Ferry D, Chandrawansa K, Schwartz JD, Ohtsu A; RAINBOW Study Group. Ramucirumab plus paclitaxel versus placebo plus paclitaxel in patients with previously treated advanced gastric or gastro-oesophageal junction adenocarcinoma (RAINBOW): a double-blind, randomised phase 3 trial. Lancet Oncol 2014;15:1224-35.

4. Bang YJ, Van Cutsem E, Feyereislova A, Chung HC, Shen L, Sawaki A, Lordick F, Ohtsu A, Omuro Y, Satoh T, Aprile G, Kulikov E, Hill J, Lehle M, Ruschoff J, Kang YK; ToGA Trial Investigators. Trastuzumab in combination with chemotherapy versus chemotherapy alone for treatment of HER2-positive advanced gastric or gastro-oesophageal junction cancer (ToGA): a phase 3, open-label, randomised controlled trial. Lancet 2010;376:687-97.

5. Yonemura Y, Endo Y, Obata T, Sasaki T. Recent advances in the treatment of peritoneal dissemination of gastrointestinal cancers by nucleoside antimetabolites. Cancer Sci 2007;98:11-8.

6. Kanda M, Kodera Y. Molecular mechanisms of peritoneal dissemination in gastric cancer. World J Gastroenterol 2016;22:6829-40.

7. Lim B, Kim C, Kim JH, Kwon WS, Lee WS, Kim JM, Park JY, Kim HS, Park KH, Kim TS, Park JL, Chung HC, Rha SY, Kim SY. Genetic alterations and their clinical implications in gastric cancer peritoneal carcinomatosis revealed by whole-exome sequencing of malignant ascites. Oncotarget 2016;7:8055-66.

8. Kurashige J, Mima K, Sawada G, Takahashi Y, Eguchi H, Sugimachi K, Mori M, Yanagihara K, Yashiro M, Hirakawa K, Baba H, Mimori K. Epigenetic modulation and repression of miR-200b by cancer-associated fibroblasts contribute to cancer invasion and peritoneal dissemination in gastric cancer. Carcinogenesis 2015;36:133-41.

9. Hanahan D, Weinberg RA. Hallmarks of cancer: the next generation. Cell 2011;144:646-74.

10. Liu X, Chu KM. E-cadherin and gastric cancer: cause, consequence, and applications. Biomed Res Int 2014;2014:637308.

11. Guilford P, Hopkins J, Harraway J, McLeod M, McLeod N, Harawira P, Taite H, Scoular R, Miller A, Reeve AE. E-cadherin germline mutations in familial gastric cancer. Nature 1998;392:402-5.

12. Kuphal F, Behrens J. E-cadherin modulates Wnt-dependent transcription in colorectal cancer cells but does not alter Wnt-independent gene expression in fibroblasts. Exp Cell Res 2006;312:457-67.

13. Kourtidis A, Lu R, Pence LJ, Anastasiadis PZ. A central role for cadherin signaling in cancer. Exp Cell Res 2017;358:78-85.

14. Asnaghi L, Vass WC, Quadri R, Day PM, Qian X, Braverman R, Papageorge AG, Lowy DR. E-cadherin negatively regulates neoplastic growth in non-small cell lung cancer: role of Rho GTPases. Oncogene 2010;29:2760-71.

15. Mao Z, Ma X, Rong Y, Cui L, Wang X, Wu W, Zhang J, Jin D. Connective tissue growth factor enhances the migration of gastric cancer through downregulation of E-cadherin via the NF-kappaB pathway. Cancer Sci 2011;102:104-10.

16. Piao HL, Yuan Y, Wang M, Sun Y, Liang H, Ma L. alpha-catenin acts as a tumour suppressor in E-cadherin-negative basal-like breast cancer by inhibiting NF-kappaB signalling. Nat Cell Biol 2014;16:245-54.

17. Janda E, Nevolo M, Lehmann K, Downward J, Beug H, Grieco M. Raf plus TGFbeta-dependent EMT is initiated by endocytosis and lysosomal degradation of E-cadherin. Oncogene 2006;25:7117-30.

18. Fukata M, Kaibuchi K. Rho-family GTPases in cadherin-mediated cell-cell adhesion. Nature Rev Mol Cell Biol 2001;2:887-97.

19. O'Connor K, Chen M. Dynamic functions of RhoA in tumor cell migration and invasion. Small GTPases 2013;4:141-7.

20. Leve F, Morgado-Diaz JA. Rho GTPase signaling in the development of colorectal cancer. J Cell Biochem 2012;113:2549-59.

21. Matsumoto S, Fujii S, Sato A, Ibuka S, Kagawa Y, Ishii M, Kikuchi A. A combination of Wnt and growth factor signaling induces Arl4c expression to form epithelial tubular structures. EMBO J 2014;33:702-18.

22. Hu Q, Takada Y, Sato K, Tobo T, Nambara S, Kidogami S, Hayashi N, Kuroda Y, Ito S, Eguchi H, Saeki H, Oki E, Maehara Y, Mimori $\mathrm{K}$. Identification of ARL4C as a peritoneal dissemination-associated gene and its clinical significance in gastric cancer. Ann Surg Oncol 2018;25:745-53.

23. Vihinen P, Kahari VM. Matrix metalloproteinases in cancer: prognostic markers and therapeutic targets. Int J Cancer 2002;99:157-66.

24. Yamada T, Oshima T, Yoshihara K, Tamura S, Kanazawa A, Inagaki D, Yamamoto N, Sato T, Fujii S, Numata K, Kunisaki C, Shiozawa M, Morinaga S, Akaike M, Rino Y, Tanaka K, Masuda M, Imada T. Overexpression of MMP-13 gene in colorectal cancer with liver metastasis. Anticancer Res 2010;30:2693-9.

25. Yonemura Y, Endou Y, Fujita H, Fushida S, Bandou E, Taniguchi K, Miwa K, Sugiyama K, Sasaki T. Role of MMP-7 in the formation of peritoneal dissemination in gastric cancer. Gastric Cancer 2000;3:63-70.

26. Peng L, Xing X, Li W, Qu L, Meng L, Lian S, Jiang B, Wu J, Shou C. PRL-3 promotes the motility, invasion, and metastasis of LoVo colon cancer cells through PRL-3-integrin beta1-ERK1/2 and-MMP2 signaling. Mol Cancer 2009;8:110.

27. Lee GH, Kim DS, Chung MJ, Chae SW, Kim HR, Chae HJ. Lysyl oxidase-like-1 enhances lung metastasis when lactate accumulation and monocarboxylate transporter expression are involved. Oncol Lett 2011;2:831-8.

28. Itoh Y, Seiki M. MT1-MMP: a potent modifier of pericellular microenvironment. J Cell Physiol 2006;206:1-8.

29. Huang J, Xiao D, Li G, Ma J, Chen P, Yuan W, Hou F, Ge J, Zhong M, Tang Y, Xia X, Chen Z. EphA2 promotes epithelial-mesenchymal transition through the Wnt/beta-catenin pathway in gastric cancer cells. Oncogene 2014;33:2737-47.

30. Peng Z, Wang CX, Fang EH, Wang GB, Tong Q. Role of epithelial-mesenchymal transition in gastric cancer initiation and progression. World J Gastroenterol 2014;20:5403-10.

31. Prieto-Garcia E, Diaz-Garcia CV, Garcia-Ruiz I, Agullo-Ortuno MT. Epithelial-to-mesenchymal transition in tumor progression. Med Oncol 2017;34:122.

32. Sciacovelli M, Frezza C. Metabolic reprogramming and epithelial-to-mesenchymal transition in cancer. FEBS J 2017;284:3132-44.

33. Xiao Q, Ge G. Lysyl oxidase, extracellular matrix remodeling and cancer metastasis. Cancer Microenviron 2012;5:261-73.

34. Kurashige J, Hasegawa T, Niida A, Sugimachi K, Deng N, Mima K, Uchi R, Sawada G, Takahashi Y, Eguchi H, Inomata M, Kitano S, 
Fukagawa T, Sasako M, Sasaki H, Sasaki S, Mori M, Yanagihara K, Baba H, Miyano S, Tan P, Mimori K. Integrated molecular profiling of human gastric cancer identifies DDR2 as a potential regulator of peritoneal dissemination. Sci Rep 2016;6:22371.

35. Gilkes DM, Semenza GL, Wirtz D. Hypoxia and the extracellular matrix: drivers of tumour metastasis. Nat Rev Cancer 2014;14:430-9.

36. Simpson CD, Anyiwe K, Schimmer AD. Anoikis resistance and tumor metastasis. Cancer Lett 2008;272:177-85.

37. Miao ZF, Wang ZN, Zhao TT, Xu YY, Gao J, Miao F, Xu HM. Peritoneal milky spots serve as a hypoxic niche and favor gastric cancer stem/progenitor cell peritoneal dissemination through hypoxia-inducible factor 1alpha. Stem Cells 2014;32:3062-74.

38. Huang D, Li T, Li X, Zhang L, Sun L, He X, Zhong X, Jia D, Song L, Semenza GL, Gao P, Zhang H. HIF-1-mediated suppression of acyl-CoA dehydrogenases and fatty acid oxidation is critical for cancer progression. Cell Rep 2014;8:1930-42.

39. Semenza GL. HIF-1 mediates metabolic responses to intratumoral hypoxia and oncogenic mutations. J Clin Invest 2013;123:3664-71.

40. Denko NC. Hypoxia, HIF1 and glucose metabolism in the solid tumour. Nat Rev Cancer 2008;8:705-13.

41. Barker HE, Cox TR, Erler JT. The rationale for targeting the LOX family in cancer. Nat Rev Cancer 2012;12:540-52.

42. Merino D, Best SA, Asselin-Labat ML, Vaillant F, Pal B, Dickins RA, Anderson RL, Strasser A, Bouillet P, Lindeman GJ, Visvader JE. Pro-apoptotic Bim suppresses breast tumor cell metastasis and is a target gene of SNAI2. Oncogene 2015;34:3926-34.

43. Smit MA, Geiger TR, Song JY, Gitelman I, Peeper DS. A Twist-Snail axis critical for TrkB-induced epithelial-mesenchymal transitionlike transformation, anoikis resistance, and metastasis. Mol Cell Biol 2009;29:3722-37.

44. Baba K, Kitajima Y, Miyake S, Nakamura J, Wakiyama K, Sato H, Okuyama K, Kitagawa H, Tanaka T, Hiraki M, Yanagihara K, Noshiro H. Hypoxia-induced ANGPTL4 sustains tumour growth and anoikis resistance through different mechanisms in scirrhous gastric cancer cell lines. Sci Rep 2017;7:11127.

45. Douma S, Van Laar T, Zevenhoven J, Meuwissen R, Van Garderen E, Peeper DS. Suppression of anoikis and induction of metastasis by the neurotrophic receptor TrkB. Nature 2004;430:1034-9.

46. Paoli P, Giannoni E, Chiarugi P. Anoikis molecular pathways and its role in cancer progression. Biochim Biophys Acta 2013;1833:3481-98.

47. Buchheit CL, Weigel KJ, Schafer ZT. Cancer cell survival during detachment from the ECM: multiple barriers to tumour progression. Nat Rev Cancer 2014;14:632-41.

48. Altomare DA, Testa JR. Perturbations of the AKT signaling pathway in human cancer. Oncogene 2005;24:7455-64.

49. Davies MA, Koul D, Dhesi H, Berman R, McDonnell TJ, McConkey D, Yung WK, Steck PA. Regulation of Akt/PKB activity, cellular growth, and apoptosis in prostate carcinoma cells by MMAC/PTEN. Cancer Res 1999;59:2551-6.

50. Vitolo MI, Weiss MB, Szmacinski M, Tahir K, Waldman T, Park BH, Martin SS, Weber DJ, Bachman KE. Deletion of PTEN promotes tumorigenic signaling, resistance to anoikis, and altered response to chemotherapeutic agents in human mammary epithelial cells. Cancer Res 2009;69:8275-83.

51. Avizienyte E, Frame MC. Src and FAK signalling controls adhesion fate and the epithelial-to-mesenchymal transition. Curr Opin Cell Biol 2005; 17:542-7.

52. Bouchard V, Demers MJ, Thibodeau S, Laquerre V, Fujita N, Tsuruo T, Beaulieu JF, Gauthier R, Vezina A, Villeneuve L, Vachon PH. Fak/Src signaling in human intestinal epithelial cell survival and anoikis: differentiation state-specific uncoupling with the PI3-K/Akt-1 and MEK/Erk pathways. J Cell Physiol 2007;212:717-28.

53. Cives M, Quaresmini D, Rizzo FM, Felici C, D’Oronzo S, Simone V, Silvestris F. Osteotropism of neuroendocrine tumors: role of the CXCL12/ CXCR4 pathway in promoting EMT in vitro. Oncotarget 2017;8:22534-49.

54. Yao C, Li P, Song H, Song F, Qu Y, Ma X, Shi R, Wu J. CXCL12/CXCR4 axis upregulates twist to induce EMT in human glioblastoma. Mol Neurobiol 2016;53:3948-53.

55. Koizumi K, Hojo S, Akashi T, Yasumoto K, Saiki I. Chemokine receptors in cancer metastasis and cancer cell-derived chemokines in host immune response. Cancer Sci 2007;98:1652-8.

56. Wendt MK, Drury LJ, Vongsa RA, Dwinell MB. Constitutive CXCL12 expression induces anoikis in colorectal carcinoma cells. Gastroenterology 2008;135:508-17.

57. van der Wal JBC, Jeekel J. Biology of the peritoneum in normal homeostasis and after surgical trauma. Colorectal Dis 2007;9:9-13.

58. Psaila B, Lyden D. The metastatic niche: adapting the foreign soil. Nat Rev Cancer 2009;9:285-93.

59. Chiang AC, Massague J. Molecular basis of metastasis. N Engl J Med 2008;359:2814-23.

60. Nishimori H, Yasoshima T, Denno R, Shishido T, Hata F, Okada Y, Ura H, Yamaguchi K, Isomura H, Sato N, Hirata K. A novel experimental mouse model of peritoneal dissemination of human gastric cancer cells: different mechanisms in peritoneal dissemination and hematogenous metastasis. Jpn J Cancer Res 2000;91:715-22.

61. Takatsuki H, Komatsu S, Sano R, Takada Y, Tsuji T. Adhesion of gastric carcinoma cells to peritoneum mediated by alpha3beta1 integrin (VLA-3). Cancer Res 2004;64:6065-70.

62. Tanaka M, Kuriyama S, Itoh G, Maeda D, Goto A, Tamiya Y, Yanagihara K, Yashiro M, Aiba N. Mesothelial cells create a novel tissue niche that facilitates gastric cancer invasion. Cancer Res 2017;77:684-95.

63. Aoyagi K, Kouhuji K, Yano S, Miyagi M, Imaizumi T, Takeda J, Shirouzu K. VEGF significance in peritoneal recurrence from gastric cancer. Gastric Cancer 2005;8:155-63.

64. Yoshikawa T, Tsuburaya A, Miyagi Y, Sekiguchi H, Kimura M, Cho H, Kobayashi O. Up-regulation of hypoxia-inducible factor-1 alpha and VEGF mRNAs in peritoneal dissemination of patients with gastric cancer. Anticancer Res 2006;26:3849-53.

65. Kamiyama M, Ichikawa Y, Ishikawa T, Chishima T, Hasegawa S, Hamaguchi Y, Nagashima Y, Miyagi Y, Mitsuhashi M, Hyndman D, Hoffman RM, Ohki S, Shimada H. VEGF receptor antisense therapy inhibits angiogenesis and peritoneal dissemination of human gastric cancer in nude mice. Cancer Gene Ther 2002;9:197-201.

66. Muro K, Chung HC, Shankaran V, Geva R, Catenacci D, Gupta S, Eder JP, Golan T, Le DT, Burtness B, McRee AJ, Lin CC, Pathiraja 
K, Lunceford J, Emancipator K, Juco J, Koshiji M, Bang YJ. Pembrolizumab for patients with PD-L1-positive advanced gastric cancer (KEYNOTE-012): a multicentre, open-label, phase 1b trial. Lancet Oncol 2016;17:717-26.

67. Kang YK, Boku N, Satoh T, Ryu MH, Chao Y, Kato K, Chung HC, Chen JS, Muro K, Kang WK, Yeh KH, Yoshikawa T, Oh SC, Bai LY, Tamura T, Lee KW, Hamamoto Y, Kim JG, Chin K, Oh DY, Minashi K, Cho JY, Tsuda M, Chen LT. Nivolumab in patients with advanced gastric or gastro-oesophageal junction cancer refractory to, or intolerant of, at least two previous chemotherapy regimens (ONO-4538-12, ATTRACTION-2): a randomised, double-blind, placebo-controlled, phase 3 trial. Lancet 2017;390:2461-71.

68. Cancer Genome Atlas Research Network. Comprehensive molecular characterization of gastric adenocarcinoma. Nature 2014;513:202-9.

69. Kamath RV, Thor AD, Wang C, Edgerton SM, Slusarczyk A, Leary DJ, Wang J, Wiley EL, Jovanovic B, Wu Q, Nayar R, Kovarik P, Shi F, Huang S. Perinucleolar compartment prevalence has an independent prognostic value for breast cancer. Cancer Res 2005;65:246-53.

70. Norton JT, Pollock CB, Wang C, Schink JC, Kim JJ, Huang S. Perinucleolar compartment prevalence is a phenotypic pancancer marker of malignancy. Cancer 2008;113:861-9.

71. Frankowski KJ, Wang C, Patnaik S, Schoenen FJ, Southall N, Li D, Teper Y, Sun W, Kandela I, Hu D, Dextras C, Knotts Z, Bian Y, Norton J, Titus S, Lewandowska MA, Wen Y, Farley KI, Griner LM, Sultan J, Meng Z, Zhou M, Vilimas T, Powers AS, Kozlov S, Nagashima K, Quadri HS, Fang M, Long C, Khanolkar O, Chen W, Kang J, Huang H, Chow E, Goldberg E, Feldman C, Xi R, Kim HR, Sahagian G, Baserga SJ, Mazar A, Ferrer M, Zheng W, Shilatifard A, Aube J, Rudloff U, Marugan JJ, Huang S. Metarrestin, a perinucleolar compartment inhibitor, effectively suppresses metastasis. Sci Trans1 Med 2018;10:eaap8307. 